\title{
Money Demand in Korea: A Cointegration Analysis, 1973-2014
}

\author{
Hyungsun Chloe Cho and Miguel D. Ramirez \\ Department of Economics, Trinity College, Hartford, CT 06106
}

Received: January 1, 2016 Accepted: January 17, 2016

doi:10.5296/ber.v6i1.8950 URL: http://dx.doi.org/10.5296/ber.v6i1.8950

\begin{abstract}
This paper estimates the demand for real money in Korea over the 1973Q3 to 2014Q4 period via unit root and cointegration methods. Utilizing the Johansen cointegration methodology and the Pantula principle, it establishes that a long-term relationship exists among the included variables. The paper also estimates an error correction model (ECM) as well as a vector error correction model (VECM), extending previous analyses by performing forecasts and testing for Granger causality among the variables. It finds that the broader definition of money, M2, serves as a relatively better measure of the money aggregate than M1 when evaluating the stability of the real demand for money. The long-term interest (LR) rate also seems to provide better results than the short-term rate (SR), which is consistent with economic theory given that it refers to a long-run equilibrium relationship. Both the ECM and VECM estimates showed the expected (and significant) signs on the coefficients; LM2 (LM1) and LGDP were positively related and LM2 (LM1) and LR (SR) were negatively related. Granger block causality tests and impulse response functions together seem to suggest that the traditional money demand function which places $M$ as its 'dependent' variable, while including income and interest rates as its regressors, was a robust and stable model in the case of Korea.
\end{abstract}

Keywords: Granger Causality test, Error correction model, Johansen contegration test, Korea, Money demand function, Phillips-Perron unit root test, Vector error correction model (VECM), Zivot Andrews single-break unit root test. JEL C22, E41, \&O5

\section{Introduction}

The central bank's monetary policy and goals often depend on its knowledge and stability of money demand, since any change in money supply can turn fruitless if it does not take into consideration the behavior of the demand side. Thus, economists and central bank officials have analyzed the stability of the money demand function, as well as its determinants, 
appropriate measures, and policy implications. Another important question is regarding the definition of money that should be used in such analysis.

For Korea, the literature seems to provide mixed evidence. Bahmani-Oskooee and Rhee (1994) find that the determinants of money demand are cointegrated with M1, but not with M2, using the Engle and Granger (EG) approach. A recent panel study on selected OECD countries including Korea also finds cointegration using M1, and the demand stays stable even during financial reforms if structural changes are allowed (Kumar et al., 2013). In another paper written with Shin, however, B-O finds a long-run equilibrium relationship among M2, income, interest rate, and exchange rate; but the money demand is found to be unstable using CUSUM and CUSUMSQ analysis (B-O and Shin, 2002). Using the Johansen method, Arize and Nam (2012) also find cointegration among the same variables for Korea, supporting an older study from Chung and Lee (1995) who find cointegration for M2, but not for M1. The implication of their study is also reinforced by Hwang (2002), who finds that the real money demand function can be measured most effectively using M2 and long-run interest rate.

This paper provides new empirical evidence regarding the demand for real money in Korea through employing unit root and cointegration methods, which include the estimation of an error correction model (ECM) as well as a vector error correction model (VECM). Furthermore, it extends previous analyses by performing forecasts and testing for Granger causality among the variables. Its findings seem to be in line with the evidence presented by Hwang (2002), as they suggest that the money demand function using the M2 aggregate and long-run interest rate presents the best VECM results.

\section{Conceptual Model}

\subsection{Money Demand Function}

Following the lead of Hwang (2002), this paper uses a simple monetarist money demand function. Monetarists assume that the demand for real money balances is a function primarily of a few economic variables including income, as a proxy of total wealth, and the interest rate, as a measure of the opportunity cost of holding money. The literature suggests that the demand for real money balances, $M$, depends positively on real income and negatively on

the nominal interest rate, $R$. The expectation of a positive relationship between money and income is reasonable: as people get wealthier, they demand more money for transactions purposes. For the interest rate, this paper assumes the traditional liquidity preference-money supply (LM) function, and consequently the working of a "liquidity effect" in the economy. In other words, as the interest rate increases, the "opportunity cost of holding cash" also increases and the demand for money decreases (Monnet and Weber, 2001). Certainly, there are more variables that are often included in the money demand function in the literature. The exchange rate is an example. Still, this paper only focuses on the two traditional determinants of real money demand. 


\subsection{Data and Variables}

We employ two different measures of real money demand, M1 and M2, in order to determine the more appropriate alternative. The International Monetary Fund (IMF) defines M1 as the sum of currency and transferable deposits, which are included in M2, the broader money aggregate. Although the components of M2 tend to vary over countries, they generally include savings deposits, time deposits, and retail money funds (IMF, 2015). Both money aggregates are measured in the national currency, the won, and are deflated by the nation's consumer price index (CPI) with $2010=100$ (FRED, Federal Reserve Bank of St. Louis). Income is measured using real gross domestic product (GDP), also in Korean won. Natural logarithms of real money aggregates and GDP, denoted by $L M 1, L M 2$, and $L G D P$, are used in order to control for potential outliers in the distribution and to make the calculation of income elasticity easier. Such logarithmic transformation of macroeconomic variables is a common procedure in the literature.

As for the interest rate, the paper considers both short-and long-term rates, each denoted as $S R$ and $L R$, respectively. Following the lead of Hwang (2002), the short-term rate is measured using the money market rate and the long-term rate using the yield on national housing bonds. Thus, four variations of the following model will be estimated:

$$
\log M_{t}=\alpha_{o}+\alpha_{1} \log G D P_{t}+\alpha_{2} R_{t}+\alpha_{3} D 1_{t}+\varepsilon_{t}
$$

where D1 is a dummy variable, equal to 1 for 1979Q4-1980Q1, 1997Q2-1998Q1, and 2008Q1; 0 otherwise. The dummy was included to assess the impact of three notable events. First, the 1979 debt crisis led to a series of significant policy changes starting in 1980 (Collins and Park, 1989). Second, the Asian financial crisis spread to Korea in 1997 and led to a shutdown of one-third of merchant banks in January, 1998. Third, the global crisis of the late 2000s had adverse effects on the country's economic growth, although they were relatively short-lived (Shin, 2013).

The data for all variables, except for SR, were obtained for the period 1973Q3 to 2014Q4;

for $S R$, the data were available starting only from 1976Q4. This paper hence includes 166 or 153 observations, depending on which proxy for the interest rate was used. With the exception of CPI figures, all data were obtained from International Financial Statistics, provided by the IMF and retrieved from Data Planet.

\section{Empirical Analysis}

\subsection{Unit Roots Analysis}

Prior to testing for cointegration, all variables were tested for unit roots. Most 
macroeconomic variables tend to exhibit deterministic and/or stochastic trends over time, which can be problematic especially when they are shared among variables that have no economic relationship. It is possible that spurious regressions will show inflated t-statistics and F-statistics, leading to incorrect conclusions. Thus, in a time series analysis, stationarity must be confirmed; or, in the case of non-stationarity, appropriate methodologies must be applied to correct for it (see Engle and Granger, 1987).

The augmented Dickey-Fuller (ADF) test and the Phillips-Perron (PP) test, which are the two conventional tests in the literature, were implemented. The PP test takes into account "the less restrictive nature of the error process (Asteriou and Hall, 2011)" by taking a non-parametric approach, or not assuming that the distribution of the error term is known and normally distributed. The PP test is therefore considered to be more 'powerful.' Accordingly, if the ADF and PP tests show conflicting results, we will defer to the PP statistics to determine the existence of unit roots. The null hypothesis in both tests is the presence of a unit root, or non-stationarity. The alternative is that of no unit root, or stationarity.

There are three possible model specifications that can be used for unit root tests. To determine the most appropriate one, this paper followed the procedure developed by Doldado et al. (1990). The ADF and PP tests are performed first using the most general model which contains both constant and a deterministic trend. If the coefficients of the two trend elements are not significant, it proceeds to test with only the constant. If the coefficient of the constant is still insignificant, the model with neither element was used to test for unit roots. As shown in Table 1, this paper finds strong evidence for non-stationarity in most variables in level form using the ADF and PP test, with the possible exception of the long-term rate at the $10 \%$ level of significance (but, for all practical purposes, this is considered too high a level of risk to reject the null of non-stationarity). $S R$ and $L R$ in first differenced form were found to be stationary, suggesting that both measures of the interest rate in this sample are integrated of order one.

Thus, based on the ADF and PP test results, the five variables of interest are determined to be integrated of the same order. ${ }^{1}$ This study also performed the Zivot-Andrews (ZA) test for one structural break using the preferred model $\mathrm{C}$ (with a constant and a trend); the estimates reported in Table 1 suggest that $L M 1, L M 2, L G D P, L R$, and $S R$ in level forms are non-stationary when a potential single structural break is taken into account. As the inclusion of D1 implies, the Korean economy underwent three major crises which are likely to have served as structural breaks, and it is well-known in the literature that the power of unit root tests is reduced significantly when the stationary alternative is true and a possible structural break is ignored; hence, the ZA test generates results that are consistent with the ADF or PP tests in this sample. Accordingly, we are able to conclude that all variable are non-stationary in level forms or integrated of order 1.

\footnotetext{
1 The confirmatory no unit root KPSS (1992) test was also performed and the results are consistent with the ADF and PP results and area available upon request.
} 
Table 1. Unit Root Test Results

\begin{tabular}{|c|c|c|c|}
\hline \multirow{2}{*}{ Variable } & \multicolumn{3}{|c|}{ Test Statistics } \\
\cline { 2 - 4 } & $A D F$ & $P P$ & $Z A$ \\
\hline$L M 1$ & -1.81 & -1.89 & -2.28 \\
\hline$L M 2$ & -1.64 & -0.69 & -2.35 \\
\hline$L G D P$ & -2.14 & -2.26 & -3.89 \\
\hline$L R$ & $-3.17^{*}$ & $-3.46^{*}$ & -3.61 \\
\hline$S R$ & -2.97 & -3.10 & -4.29 \\
\hline$\Delta L M 1$ & $-4.72^{* * *}$ & $-12.34^{* * *}$ & --- \\
\hline$\Delta L M 2$ & $-3.56^{* * *}$ & $-8.71^{* * *}$ & --- \\
\hline$\Delta L R$ & $-11.21^{* * *}$ & $-11.20^{* * *}$ & \\
\hline$\triangle S R$ & $-10.24^{* * *}$ & $-10.54^{* * *}$ & --- \\
\hline$\triangle L G D P$ & $-3.22^{*}$ & $-33.56^{* * *}$ & \\
\hline
\end{tabular}

Significance levels: $1 \% * * *, 5 \% * *$, and $10 \% *$.

\subsection{Cointegration Analysis}

Since all variables appear to contain unit roots in their level form, we proceed to test for cointegration, or the existence of a long-run equilibrium relationship. Residuals of the ordinary least-squares (OLS) estimations were shown to be stationary in the ADF and PP tests, indicating the presence of a cointegrating relationship. ${ }^{2}$ However, the simple Engle-Granger (EG) approach, although suggestive, does not provide very reliable results for cointegration in equation (1) for several reasons. First, since the equation includes more than two variables, there may be more than one cointegrating relationship. The EG test cannot account for this possibility, and might induce specification errors. Second, the test uses the money aggregate as the 'dependent' variable and other variables as regressors, without considering a different ordering - for instance, LGDP could be placed on the left-hand side instead of $L M$. Lastly, it is a two-step process that involves the generation of residuals, first, and test for unit roots, second. In such a process, errors from the first step can be carried over to the next step (see Asteriou and Hall, 2011).

So instead, we utilize the Johansen (1990) methodology, which uses a multiple-equation method to determine the number of maximum cointegrating vectors (n-1). To determine the appropriate number of lags, the paper first estimated a regular vector autoregressive (VAR) models, starting with a leg length of six and then gradually reducing it until the lowest Schwarz value was attained. As expected for quarterly data, four was determined to be the optimal length of lag. Having established the lag length, we proceeded to evaluate three possible model specifications in the multivariate system for each case. Following the Pantula principle (1989), trace statistics for models 2, 3, and 4 were compared in order, starting with the smallest number of cointegrating vector and stopping when the null hypothesis of no cointegration cannot be rejected for the first time. The Johansen test results are presented in

\footnotetext{
2 The OLS estimations and unit root test results for their residuals can be provided upon request.
} 


\section{Macrothink}

Business and Economic Research

ISSN 2162-4860 2016, Vol. 6, No. 1

Table 2. The trace statistics suggest that either models 3 or 4 are appropriate for analysis using $L R$, while model 4 is appropriate for $S R$. There seems to be at least one cointegrating equation in all four cases (and at most two cointegrating vectors given that there are three quantitative variables in the money demand equation); in other words, a long-run equilibrium relationship among the money aggregates and its determinants seems to exist for the case of Korea, which is an important finding in the literature.

Table 2. Johansen Test Results

\begin{tabular}{|c|c|c|c|c|c|c|}
\hline \multirow[b]{2}{*}{ \# of CE } & \multicolumn{3}{|c|}{ Trace Statistics } & \multicolumn{3}{|c|}{ Maximum Eigenvalue Statistics } \\
\hline & Model 2 & Model 3 & Model 4 & Model 2 & Model 3 & Model 4 \\
\hline \multicolumn{7}{|c|}{ Group 1: LM1, LGDP, and LR } \\
\hline 0 & $63.02 * *$ & $57.10 * *$ & $59.68 * *$ & $37.01 * *$ & $35.32 * *$ & $37.08 * *$ \\
\hline 1 & $26.00 * *$ & $21.77 * *$ & 22.59 & 18.20 & 14.01 & 14.06 \\
\hline 2 & 7.80 & $7.77 * *$ & 8.54 & 7.81 & $7.76^{* *}$ & 8.54 \\
\hline \multicolumn{7}{|c|}{ Group 2:LM2, LGDP, and LR } \\
\hline 0 & $60.67 * *$ & $57.03 * *$ & $65.35 * *$ & $32.93 * *$ & $31.86^{* *}$ & $34 . .53 * *$ \\
\hline 1 & $27.74 * *$ & $25.16^{* *}$ & $30.83 * *$ & 20.11 & $17.61 * *$ & $21.19 * *$ \\
\hline 2 & 7.69 & $7.56 * *$ & 9.63 & 7.69 & $7.55 * *$ & 9.63 \\
\hline \multicolumn{7}{|c|}{ Group 3:LM1, LGDP, and SR } \\
\hline 0 & $49.49 * *$ & $42.38 * *$ & $47.53 * *$ & $30.14 * *$ & $23.73 * *$ & $25.00 * *$ \\
\hline 1 & 19.35 & $18.65^{* *}$ & 22.54 & 14.64 & $14.26^{* *}$ & 16.47 \\
\hline 2 & 4.71 & $4.38 * *$ & 6.06 & 4.22 & $4.38 * *$ & 6.06 \\
\hline \multicolumn{7}{|c|}{ Group 4:LM2, LGDP, and SR } \\
\hline 0 & $49.20 * *$ & $44.54 * *$ & $52.33 * *$ & $26.70 * *$ & $24.89 * *$ & $25.68 * *$ \\
\hline 1 & 19.86 & $19.65^{* *}$ & 26.65 & 9.16 & $15.61 * *$ & $19.41 * *$ \\
\hline 2 & 4.26 & 4.04 & 7.24 & 5.46 & 4.05 & 7.23 \\
\hline
\end{tabular}

Note: The null hypothesis cannot be rejected for the first time is highlighted; **denotes significance at $5 \%$ level.

\subsection{Error Correction Model (ECM)}

In order to "reconcile the short-run dynamics to the long-run relationship," an ECM was first estimated for each four group of variables. The ECM, usually utilized for cointegrated $I(1)$ series, differences the data to capture the short-run relationships and also includes the lagged residual terms as a regressor to capture the long-run effects (Asteriou and Hall, 2011). The ECM is mathematically represented as:

$$
\Delta \log M_{t}=\beta_{0}+\beta_{1} \Delta \log G D P_{t}+\beta_{2} \Delta R_{t}+\beta_{3} D 1_{t}+\hat{\varepsilon}_{t-1}+u_{t}
$$


The estimates are shown in Table 3. The coefficients for DLGDP, DLR, and DSR have signs that are expected and consistent with the economic relationship discussed in the second section. The dummy variable is highly significant in all specifications but gives conflicting signs, viz., negative for M1 but positive for M2. A possible explanation is that during times of crisis and uncertainty, economic agents in Korea shift funds out of M1 into the broader money aggregate which includes savings and time deposits. The adjusted R-sq. terms are reasonable for this type of differenced model and the F-stats suggest that the models as a whole are highly significant in explaining the variation in the real money aggregates.

Table 3. Error Correction Model

\begin{tabular}{|l|c|c|c|c|}
\hline & $\begin{array}{c}\text { Group 1 } \\
\text { DLM1 }\end{array}$ & $\begin{array}{c}\text { Group 2 } \\
D L M 2\end{array}$ & $\begin{array}{c}\text { Group 3 } \\
D L M 1\end{array}$ & $\begin{array}{c}\text { Group 4 } \\
D L M 2\end{array}$ \\
\hline C & $\begin{array}{c}0.0185 \\
(4.52)^{* *}\end{array}$ & $\begin{array}{c}0.019 \\
(5.92)^{* *}\end{array}$ & $\begin{array}{c}0.017 \\
(4.01)^{* *}\end{array}$ & $\begin{array}{c}0.020 \\
(5.36)^{* *}\end{array}$ \\
\hline DLGDP & $\begin{array}{c}0.227 \\
(3.13)^{* *}\end{array}$ & $\begin{array}{c}0.297 \\
(2.11)^{* *}\end{array}$ & $\begin{array}{c}0.282 \\
(5.11)^{* *}\end{array}$ & $\begin{array}{c}0.339 \\
(2.21)^{* *}\end{array}$ \\
\hline DLR & -0.005 & -0.003 & & - \\
$(-2.07)^{* *}$ & $(-2.05)^{* *}$ & - & - \\
\hline DSR & - & - & -0.0050 & -0.002 \\
& & $-1.91)^{* *}$ & $(-1.45)^{*}$ \\
\hline ECT(-1) & -0.110 & -0.052 & -0.101 & -0.051 \\
$(-3.63)^{* *}$ & $(-5.16)^{* *}$ & $(-3.10)^{* *}$ & $(-3.98)^{* *}$ \\
\hline D1 & -0.050 & 0.031 & -0.050 & 0.032 \\
$(-2.79)^{* *}$ & $(3.97)^{* *}$ & $(-2.57)^{* *}$ & $(3.79)^{* *}$ \\
\hline R-sq & 0.266 & 0.226 & 0.302 & 0.213 \\
\hline Adj $R$-sq & 0.247 & 0.207 & 0.282 & 0.192 \\
\hline F-statistic & $14.269^{* *}$ & $11.619^{* *}$ & $15.788^{* *}$ & $9.903^{* *}$ \\
\hline Schwarz & -3.098 & -4.658 & -3.147 & -4.790 \\
\hline
\end{tabular}

Note: t-statistics are given in parentheses below the estimated coefficients;

$* *$ denotes significance at the $5 \%$ level.

The error correction terms (ECT) for all four groups had significant negative signs, and ranged approximately between -0.05 to -0.11 . Hence, $L M 1$ and $L M 2$ both seem to have a long-run equilibrium relationship to which they revert at a reasonable adjustment speed. For example, if the real money aggregate (M1) exceeds its predicted long-run value by $100 \%$, it will decrease by $11 \%$ on average in the following quarter or $44 \%$ on an annual basis.

The ECMs were then used to create in-sample forecasts, presented in Figure 1. Figure 2 shows the forecast result for 2011Q1 to 2014Q4, taken as an out-of-sample. To do this, the ECMs were re-estimated for the period 1979Q3-2010Q4 or 1976Q4-2010Q4. Then, the estimates were used to forecast actual values for the next 16 time periods. For in-sample 
forecasts, Theil inequality coefficients are close to the general cutoff line of 0.3 and there is no bias (see Theil, 1966). For out-of-sample forecasts, evaluation measures were not close to their optimal values. Still, turning points in the actual data seem to be predicted by the ECMs relatively well in both cases.
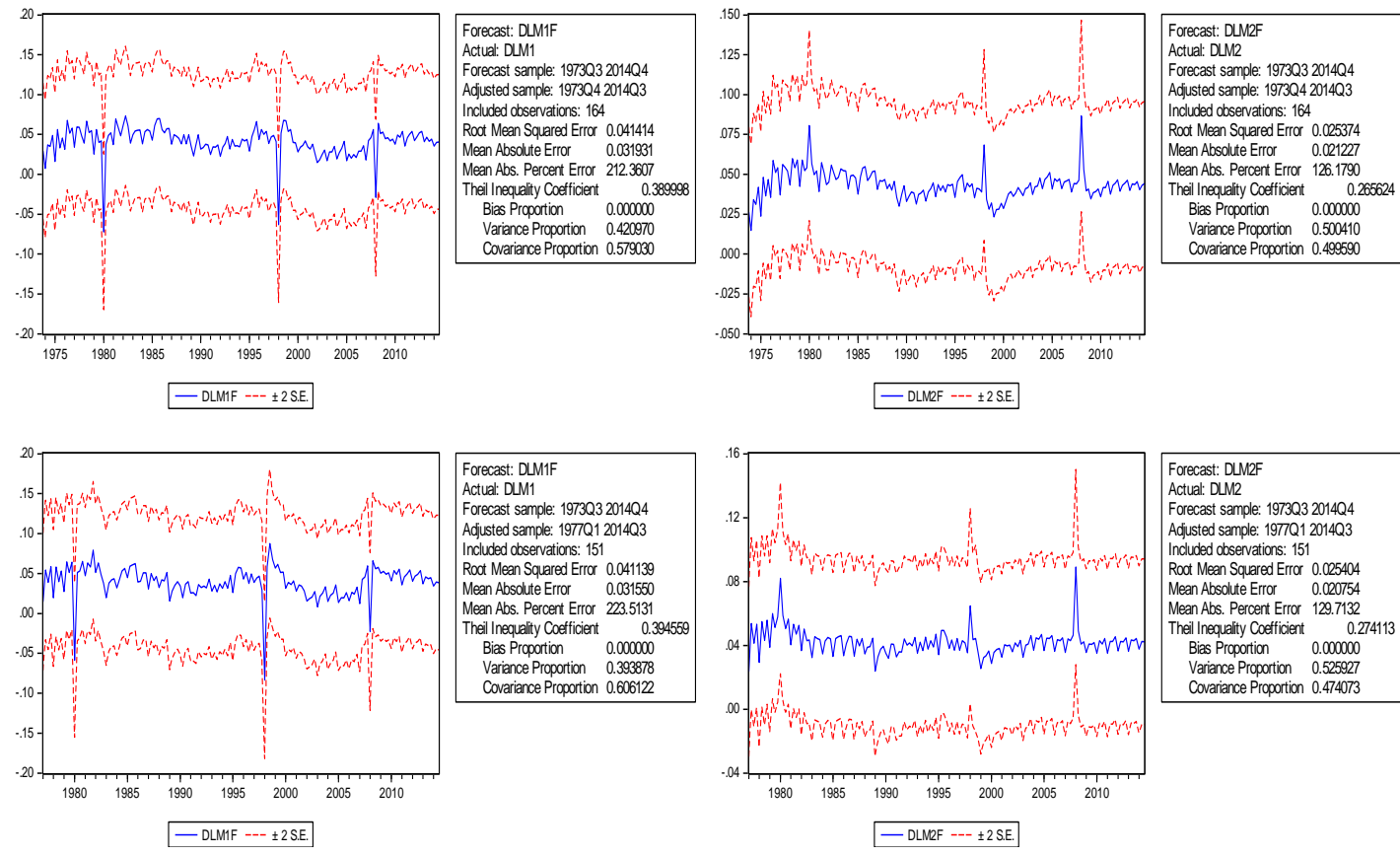

Figure 1. In-Sample Forecast
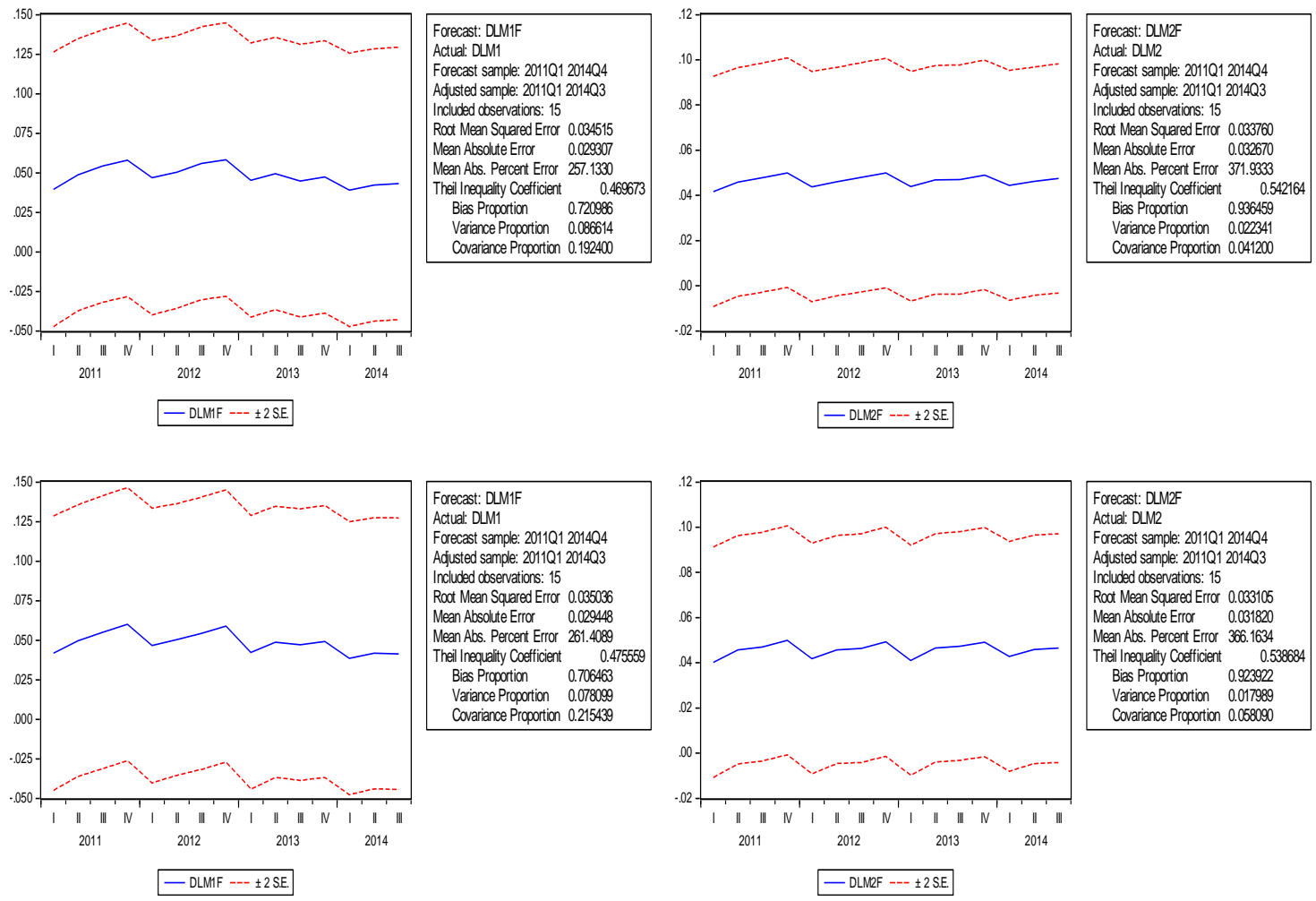

Figure 2. Out-of-Sample Forecast 


\subsection{Vector Error Correction Model (VECM)}

Next, a VECM is estimated because it addresses the drawbacks of the popular EG approach which were previously discussed. The VECM framework will treat all variables in the money demand function as endogenous, instead of assuming exogeneity based on the standard theory (see Ramirez and Komuves, 2014). It was suggested before that the direction of causality might run from the regressors to $M 1$ or $M 2$, or from one regressor to another. The VECM, by transforming the single-equation ECM to a multivariate one, controls for this potential endogeneity (see Asteriou and Hall, 2011).

Given the results of the Johansen tests which found at least one cointegrating relationship for all four groups, the paper proceeded to estimate the VECM using four lags and the appropriate model was determined using the Pantula procedure for each group. The normalized long-run coefficients in the unrestricted VECM for group 2, estimated using $L M 2, L G D P$, and $L R$, were significant and showed the expected signs (the results for group 1 were also significant and showed the expected signs but are not reported due to space constraints). The Akaike (AIC), Schwarz (SBC), and adjusted R-squared values suggest that the equation using $L G D P$ as the 'dependent' variable is the best specification for group 2; however, the adjustment coefficient for $L G D P$ in the model is positive and statistically significant. The results are similar for the fourth group, with $L M 2$ and $S R$. The model with LM2 as the regressand, which displays the lowest AIC and SBC values, shows a positive adjustment coefficient which is highly significant. The VECM for group 3 presents the least reasonable result, with a significantly negative normalized coefficient on short-term rate. The coefficient of $L G D P$ is also in unexpected direction, although insignificant (see Table 4 below).

Table 4. Vector Error Correction Models (Groups 2, 3, and 4)

Cointegration Coefficients

\begin{tabular}{|c|c|c|c|c|c|c|c|}
\hline & $L M 1$ & $L M 2$ & $L G D P$ & $L R$ & $S R$ & TREND & $C$ \\
\hline Group 2 & - & 1.0000 & $\begin{array}{r}-1.1058 \\
(-9.80)\end{array}$ & $\begin{array}{c}0.0712 \\
(5.34)\end{array}$ & - & $\begin{array}{c}0.0063 \\
(1.54)\end{array}$ & 10.22 \\
\hline Group 3 & 1.0000 & - & $\begin{array}{c}1.1825 \\
(0.98)\end{array}$ & - & $\begin{array}{c}-0.4082 \\
(-3.71)\end{array}$ & $\begin{array}{c}-0.0402 \\
(-1.06)\end{array}$ & -62.08 \\
\hline Group 4 & - & 1.0000 & $\begin{array}{r}-2.8600 \\
(-4.59)\end{array}$ & - & $\begin{array}{c}0.2469 \\
(3.87)\end{array}$ & $\begin{array}{c}0.0230 \\
(1.22)\end{array}$ & 53.93 \\
\hline
\end{tabular}


Error Correction Table

\begin{tabular}{|l|c|c|c|c|c|c|c|c|c|}
\hline & \multicolumn{3}{|c|}{ Group 2 } & \multicolumn{3}{c|}{ Group 3 } & \multicolumn{4}{c|}{ Group 4 } \\
\hline & $D(L M 2)$ & $D(L G D P)$ & $D(L R)$ & $D(L M 1)$ & $D(L G D P)$ & $D(S R)$ & $D(L M 2)$ & $D(L G D P)$ & $D(S R)$ \\
\hline \multirow{2}{*}{ oE $q$} & 0.0284 & 0.0135 & -0.98 & -0.0046 & -0.0012 & 0.2877 & 0.0042 & 0.0015 & -0.4939 \\
& $(3.24)$ & $(2.50)$ & $(-4.31)$ & $(-2.92)$ & $(-1.42)$ & $(5.91)$ & $(2.42)$ & $(0.63)$ & $(-3.61)$ \\
\hline R-sq & 0.3081 & 0.9231 & 0.2676 & 0.3519 & 0.9273 & 0.4707 & 0.6994 & 0.9261 & 0.4573 \\
\hline Adj $R$-sq & 0.2413 & 0.9157 & 0.1969 & 0.2831 & 0.9195 & 0.4146 & 0.6675 & 0.9182 & 0.3998 \\
\hline Akaike & -3.5190 & -4.4935 & 2.9928 & -3.5725 & -4.8534 & 3.2861 & -5.4485 & -4.8374 & 3.3112 \\
\hline Schwarz & -3.2307 & -4.2052 & 3.2811 & -3.2673 & -4.5483 & 3.5913 & -5.1433 & -4.5323 & 3.6163 \\
\hline
\end{tabular}

Since the Johansen test suggested at most two cointegrating equations based on trace statistics but only one based on the more powerful max-eigenvalue test for the second group, two VECMs were calculated; the rank of $\Pi$, or the number of cointegrating vectors, was set equal to one and then to two. The results are provided in Table 5. The estimates with one cointegrating vector seem to be the better of the two, providing results consistent with both economic theory and the Johansen max-eigenvalue test. The VECM displays significant and expected signs of normalized coefficients. In this model, the long-run income elasticity of money demand is estimated to be 1.594. In other words, a ceteris paribus one percent change in real GDP will induce M2 to increase by 1.594 percent.

The adjustment coefficient on $D(L M 2)$ is, as suggested by economic theory, negative in direction and barely significant at the 5\% level, suggesting that it is not weakly exogenous. However, weak exogeneity in the VECM is found when a variable is only a function of lagged variables and is generated by parameters that are independent of those generating by other variables in the system (Asteriou and Hall, 2011). To test formally for weak exogeneity, the restriction $A(1,1)=0$ was imposed on the first adjustment coefficient in the VECM reported in Table 5. The Chi-square value of 2.616 was insignificant at all levels and we fail to reject the null hypothesis of exogeneity. The likelihood test was performed for $L G D P$ and

$L R$ as well. The results are given in Table 6 and show that the null of exogeneity is rejected at the $5 \%$ level for both variables, Thus, the results suggest that only $L M 2$ is weakly exogenous in the system. 
Table 5. Vector Error Correction Model (for Group 2)

Cointegration Coefficients

\begin{tabular}{|c|c|c|c|c|c|}
\hline & $L M 2$ & $L G D P$ & $L R$ & $T R E N D$ & $C$ \\
\hline \multirow{2}{*}{$\Pi=1$} & 1.0000 & $\begin{array}{c}-1.5944 \\
(-9.82)\end{array}$ & $\begin{array}{c}0.0571 \\
(4.10)\end{array}$ & $\begin{array}{c}0.0069 \\
(1.62)\end{array}$ & 2.03 \\
\hline \multirow{4}{*}{$\Pi=2$} & 1.0000 & 0.0000 & $\begin{array}{r}-2.550 \\
(-3.46)\end{array}$ & $\begin{array}{r}0.0959 \\
(0.74)\end{array}$ & -10.61 \\
\cline { 2 - 6 } & 0.0000 & 1.0000 & $\begin{array}{r}-2.371 \\
(-3.51)\end{array}$ & $\begin{array}{c}0.081 \\
(0.68)\end{array}$ & -9.78 \\
\hline
\end{tabular}

Error Correction Table

\begin{tabular}{|l|c|c|c|c|c|c|}
\hline & \multicolumn{3}{|c|}{$\Pi=1$} & \multicolumn{3}{c|}{$\Pi=2$} \\
\hline & $D(L M 2)$ & $D(L G D P)$ & $D(L R)$ & $D(L M 2)$ & $D(L G D P)$ & $D(S R)$ \\
\hline \multirow{2}{*}{ CoEq1 } & -0.0133 & 0.0337 & -1.5119 & -0.0596 & 0.5434 & -0.9669 \\
& $(-1.93)$ & $(4.03)$ & $(-4.09)$ & $(-3.88)$ & $(2.91)$ & $(-0.80)$ \\
\hline \multirow{2}{*}{ CoEq2 } & - & - & - & 0.0701 & -0.0658 & 1.5829 \\
& & & & $(3.87)$ & $(-2.98)$ & $(1.11)$ \\
\hline R-sq & 0.3910 & 0.9248 & 0.2147 & 0.5122 & 0.9308 & 0.3787 \\
\hline Adj $R$-sq & 0.3322 & 0.9176 & 0.1389 & 0.4563 & 0.9229 & 0.3076 \\
\hline Akaike & -5.908 & -4.516 & 3.068 & -5.281 & -4.890 & 3.495 \\
\hline Schwarz & -4.616 & -4.228 & 3.350 & -4.955 & -4.565 & 3.785 \\
\hline
\end{tabular}

Table 6. Weak Exogeneity Test Results

\begin{tabular}{|c|c|c|}
\hline Imposed Restriction & Chi-square Statistics & Probability \\
\hline $\mathrm{A}(1,1)=0$ for $L M 2$ & 2.616 & 0.1057 \\
\hline $\mathrm{A}(2,1)=0$ for $L G D P$ & $12.144^{* *}$ & 0.0005 \\
\hline $\mathrm{A}(3,1)=0$ for $L R$ & $11.397 * *$ & 0.0007 \\
\hline
\end{tabular}

To further test for "causal" relationships among the variables, we undertook a test for Granger causality, treating $L M 2$ as exogenous. Both pairwise and block exogeneity Granger causality tests were used (see Table 7 for the results). The pairwise test, which assumes that only the particular pair of variables is endogenous in the VECM, suggests that causality does run from income and the long-term interest rate to $\mathrm{M} 2$, as well as from interest rate to income and also the other way around. However, this test tends to be less powerful than the block exogeneity test, which fails to reject the null of no Granger causality for $D L R$ to $D L M 2$, but suggests that DLM2 Granger causes DLR. Collectively, the two tests provide evidence for Granger causality running from $D L G D P$ to $D L M 2 ; D L R$ to $D L G D P$; and $D L G D P$ to 
$D L R$.

Table 7. Granger Causality Test Results

Pairwise Test

\begin{tabular}{|l|r|r|r|}
\hline Null Hypothesis & Obs & F-Statistic & Prob. \\
\hline$D L G D P$ does not Granger Cause $D L M 2$ & 160 & $2.9857 * *$ & 0.0209 \\
\hline$D L M 2$ does not Granger Cause $D L G D P$ & & 1.6750 & 0.1587 \\
\hline$D L R$ does not Granger Cause $D L M 2$ & 161 & $2.4219 * *$ & 0.0507 \\
\hline$D L M 2$ does not Granger Cause $D L R$ & & 0.8455 & 0.4984 \\
\hline$D L R$ does not Granger Cause $D L G D P$ & 160 & $2.3790^{* *}$ & 0.0543 \\
\hline$D L G D P$ does not Granger Cause $D L R$ & & $2.0497 *$ & 0.0903 \\
\hline
\end{tabular}

Block Exogeneity Test

\begin{tabular}{|c|c|c|c|}
\hline \multicolumn{3}{|l|}{ Dependent variable: $D(L M 2)$} & \\
\hline Excluded & Chi-sq & Df & Prob. \\
\hline$D(L G D P)$ & $8.2150^{*}$ & 4 & 0.084 \\
\hline$D(L R)$ & 7.209 & 4 & 0.1252 \\
\hline All & 14.3635 & 8 & 0.0728 \\
\hline Dependent variable: $D(L G D P)$ & \\
\hline Excluded & Chi-sq & Df & Prob. \\
\hline$D(L M 2)$ & 0.723 & 4 & 0.9485 \\
\hline$D(L R)$ & $8.6933^{*}$ & 4 & 0.0692 \\
\hline All & 10.9385 & 8 & 0.2052 \\
\hline Dependent variable: $D(L R)$ & \\
\hline Excluded & Chi-sq & Df & Prob. \\
\hline$D(L M 2)$ & $9.3911^{* *}$ & 4 & 0.052 \\
\hline$D(L G D P)$ & $33.0852^{* * *}$ & 4 & 0 \\
\hline All & 39.5493 & 8 & 0 \\
\hline
\end{tabular}

The impulse response functions, shown in Figure 3, seem to support the Granger causality test results. Following the lead of Ramirez and Komuves (2014), this paper utilized the generalized decomposition process developed by Pesaran and Shin (1998). The generalized process, in comparison to the Cholesky decomposition, tends to be less sensitive to the ordering of the variables. The impulse responses show that the response of $L M 2$ to a one standard deviation innovation in $L G D P$ is positive and sustained throughout the twenty time periods. The response of $L M 2$ to the innovation in $L R$, although not as significant, also 
seems to be sustained. The response of $L G D P$ to $L R$, and the reverse, seems to be strong, again confirming the Granger causality test results.
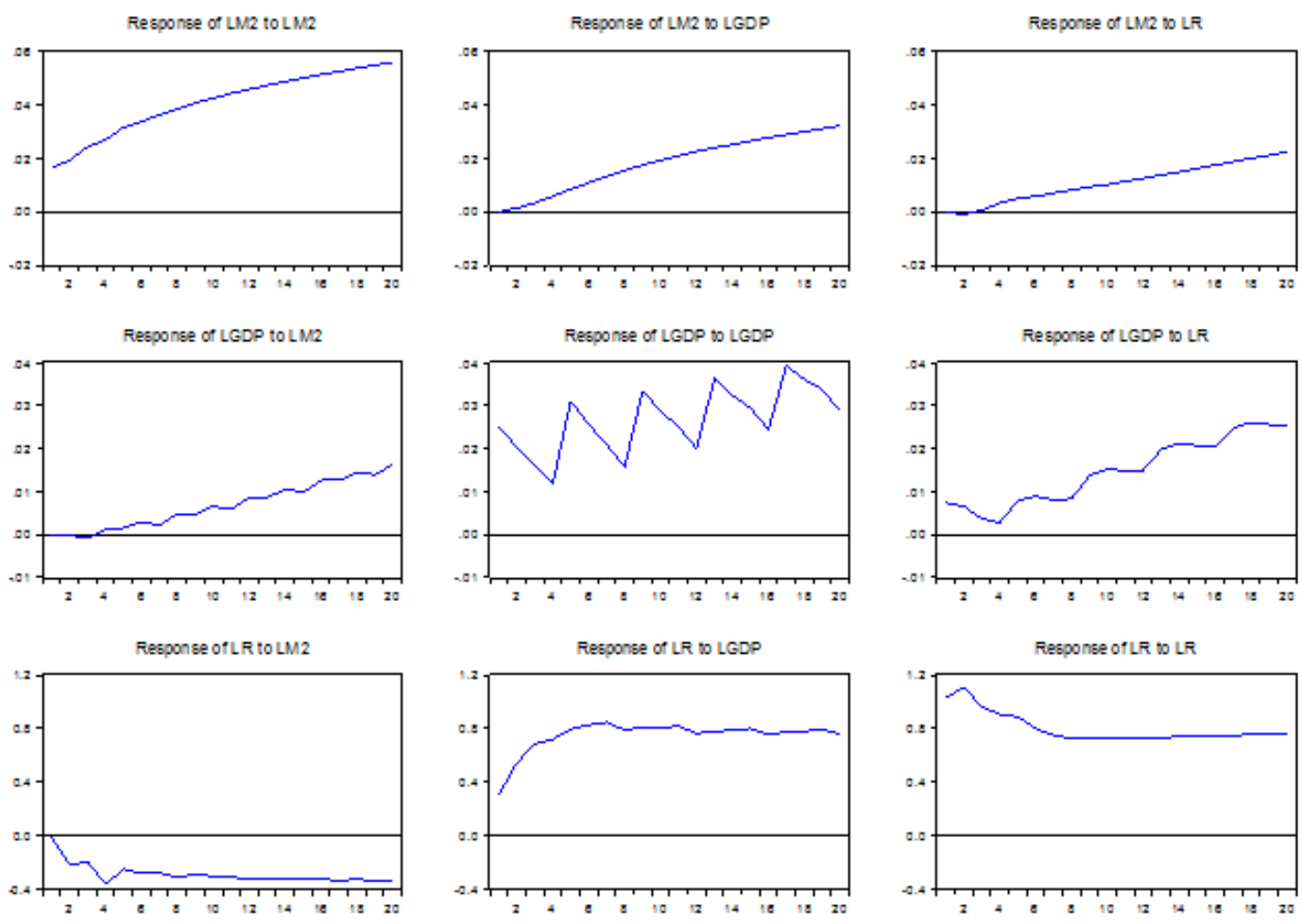

Figure 3. Impulse Responses

\section{Conclusion}

This paper has made an important finding that there is a long-run relationship among real money aggregates, real income measured as real GDP, and short- and long-run interest rates in Korea over the period 1973Q3 to 2014Q4, or 1976Q4 to 2014Q4. The assessment of four different combinations of variables provides supporting evidence for the popular claim that M2, the broader definition of money, serves as the relatively better measure of the money aggregate than M1 when evaluating the stability of the real money demand function. Still, the results for the narrow definition of money, M1, are also consistent with economic theory and the reported findings in the literature for Korea. The long-term interest rate also seems to provide relatively better results than the short-term rate, which is consistent with both economic theory and cointegration analysis given that it refers to a long-run equilibrium relationship. Both the ECM and VECM estimates showed the expected signs (the latter based on the normalized coefficients); $L M 2$ (LM1) and $L G D P$ were positively related and

$L M 2(L M 1)$ and $L R(S R)$ were negatively related. The adjustment coefficient in the VECM suggested that the money aggregate was weakly exogenous. Granger block causality tests and impulse response functions together suggest that the traditional money demand function, 
which places $M$ as its 'dependent' variable while including income and interest rates as its regressors, was a robust and stable model in the specific case of Korea over the period under review.

\section{References}

Asteriou, D., \& Hall, S. G. (2011). Applied Econometrics (2nd ed.). NYC: Palgrave Macmillan.

Arize, A. C., \& Nam, K. (2012). The Demand for Money in Asia: Some Further Evidence. International Journal of Economics and Finance, 4(8), 1916-9728. http://dx.doi.org/10.5539/ijef.v4n8p59

Bahmani-Oskooee, M., \& Rhee, H. J. (1994). Long-Run Elasticities of the Demand for Money in Korea: Evidence from Cointegration Analysis. International Economic Journal, 8, 83-93. http://dx.doi.org/10.1080/10168739400080015

Bahmani-Oskooee, M., \& Shin, S. (2006). Stability of the Demand for Money in Korea. International Economic Journal, $16(2), \quad$ 85-95. http://dx.doi.org/10.1080/10168730200080015

Chung, K. J., \& Lee, T. H. (1995). Further Results on the Long-Run Demand for Money in Korea: A Cointegration Analysis. International Economics Journal, 9, 103-13. http://dx.doi.org/10.1080/10168739500000024

Collins, S. M., \& Park, W. (1989). External Debt and Macroeconomic Performance in South Korea. In J. D. Sachs (Eds.), Developing Country Debt and the World Economy (121-140). Chicago, IL: University of Chicago Press.

Dickey, D. A., \& Fuller, W. A. (1981). Likelihood Ratio Statistics for Autoregressive Time Series with a Unit Root. Econometrica, 49(4), 1057-1072. http://dx.doi.org/10.2307/1912517

Doldado, J., Jenkinson, T., \& Sosvilla-Rivero, S. (1990). Cointegration and Unit Roots. $\begin{array}{lllll}\text { Journal of } & \text { Economic } & \text { Surveys, } & 4,\end{array}$ http://dx.doi.org/10.1111/j.1467-6419.1990.tb00088.x

Engle, R. F., \& Granger, C. W. J. (1987). Cointegration and Error Correction: Representation, Estimation, and Testing. Econometrica, 55, 252-276. http://dx.doi.org/10.2307/1913236

Hwang, J. (2002). The Demand for Money in Korea: Evidence from the Cointegration Test. International Advances in Economic Research, 8(3), 188-195. http://dx.doi.org/10.1007/BF02297956

International Monetary Fund. (2015). M1 for United States and M2 for United States. Retrieved from the Federal Reserve Bank of St. Louis, https://research.stlouisfed.org/.

Johansen, S., \& Juselius, K. (1990). Maximum Likelihood Estimation and Inference on Cointegration with Applications to the Demand for Money. Oxford Bulletin of Economics and Statistics, 52(2), 169- 210. http://dx.doi.org/10.1111/j.1468-0084.1990.mp52002003.x 


\section{Macrothink}

Business and Economic Research ISSN 2162-4860

Kumar, S., Chowdhury, M. B., \& Rao, B. B. (2013). Demand for Money in the Selected OECD Countries: A Time Series Panel Data Approach and Structural Breaks. Applied Economics, 45, 1767-1776. http://dx.doi.org/10.1080/00036846.2011.637897

Kwiatkowski, D., et al. (1992). Testing the Null Hypothesis of Stationarity Against the Alternative of a Unit Root. Journal of Econometrics, 54, 159-178. http://dx.doi.org/10.1016/0304-4076(92)90104-Y

Monnet, C., \& Weber, W. E. (2001). Money and Interest Rates. Federal Reserve Bank of Minneapolis Quarterly Review, 25(4), 2-13.

Pantula, S. G. (1989). Testing for Unit roots in Time Series Data. Economic Theory, 5, 256-271. http://dx.doi.org/10.1017/S0266466600012421

Pesaran, M. H., \& Shin, Y. (1998). Impulse Response Analysis in Linear Multivariate Models. Economic Letters, 58, 17-29. http://dx.doi.org/10.1016/S0165-1765(97)00214-0

Ramirez, M. D., \& Komuves, Z. (2014). Economic Infrastructure, Private Capital Formation, and FDI Inflows to Hungary: A Unit Root and Cointegration Analysis with Structural Breaks. Atlantic Economic Journal, 42(4), 367-382. http://dx.doi.org/10.1007/s11293-014-9436-0

Shin, J. (2013). The Global Financial Crisis and the Korean Economy. NYC: Routledge.

Theil, H. (1966). Applied Economic Forecasting. Amsterdam: North-Holland.

\section{Copyright Disclaimer}

Copyright for this article is retained by the author(s), with first publication rights granted to the journal.

This is an open-access article distributed under the terms and conditions of the Creative Commons Attribution license (http://creativecommons.org/licenses/by/3.0/). 